\title{
SOCIOECONOMIC CHARACTERISTICS OF RURAL FARMERS AND PROBLEMS ASSOCIATED WITH THE USE OF INFORMAL INSURANCE MEASURES IN ODOGBOLU LOCAL GOVERNMENT AREA, OGUN STATE, NIGERIA
}

\author{
Ogunmefun S.O., Achike A.I., Researchers \\ Department of Agricultural Economics, University of Nigeria, Nsukka, Enugu State, Nigeria \\ Email: donoluwilliams@gmail.com, ifyachike@gmail.com
}

\begin{abstract}
This study analyzed the socioeconomic characteristics of rural farmers and problems associated with the use of informal insurance measures in Odogbolu Local Government Area of Ogun state, Nigeria. To give effect to the study, eighty farmers were randomly selected from the study area. A two-stage sampling procedure was used in the collection of primary data in Odogbolu LGA. The first stage involved a random selection of five (5) communities from amongst the communities in Odogbolu LGA of Ogun state. The second stage involved the selection of respondents/farmers from each of the communities using the same insurance practices from the already listed informal insurance practices with probability proportionate to the size of each farming communities selected. Data collected through structured questionnaires and interview schedules were analyzed using frequency distribution such as mean and percentage. Results showed all the measures used had factors that limited their effectiveness. Majority of the farmers $(61 \%)$ identified their major problems with the use of informal insurance measures as entry constraints which was grouped into lack of credit, lack of credit facilities, Lack of working capital (assets like land) and lack of skills (education). Recommendation for this study is that farmers should be encouraged to invest more and increase their input in agriculture as to improve their output/revenue. Also, the government should give concessions to the rural farmers in various aspects which include provision of credit facilities, provision of infrastructures and inputs for rural farmers to enable them perform most of the informal insurance measures.
\end{abstract}

\section{KEY WORDS}

Farming; Insurance; Community; Education.

Many low-income countries, from Sub-Saharan Africa to Southeast Asia, have suffered major natural disasters and political upheavals through the 1990s. These events remind observers about what is hidden in official poverty statistics: that the condition of poverty is linked closely to vulnerability. Many agrarian households are exposed regularly to risks from poor weather, illness, political instability, and economic mismanagement. Concern with vulnerability may be both intrinsic and tied to implications for income generation, as well as longer-term consequences on the nutrition, health, and schooling of children (Rose, 1995; Hoddinott and Kinsey, 1998; and Jacoby and Skoufias, 1997). Fear of risk can lead agrarian households to forego potentially valuable new technologies and profitable production choices. Rosenzweig and Binswanger (1993), for example, use data from rural South India to show that an increase in risk leads to reductions in farm profits by $35 \%$ for the poorest quarter of households, while the wealthiest (and least vulnerable) farmers are virtually unaffected. Vulnerable households may also spiral downward into ongoing poverty following adverse economic or climatic shocks, as productive assets are depleted to protect consumption levels. Addressing risk can thus be an important complement to redistributive efforts and anti-poverty strategies focused on increasing economic growth and employment. Yet, even with holes in public safety nets and private insurance markets, poor households are not completely exposed to risk. Most have developed coping strategies to deal with the harshest setback. The bulk of mechanisms are provided neither by the market nor the state but instead are "informal insurance," arising between individuals and communities on a personalized basis. Examples include drawing down savings, engaging in reciprocal needbased gift exchange, selling physical assets, and diversifying crops and income-generating activities (Mauss, 1967). 
According to Estacio and Mordeno. (2001), agriculture is very much vulnerable to the unpredictability of nature. With agricultural production representing the major source of income of many resource constrained Ogun state farmers, the impact of nature and other agricultural risk cannot be taken lightly. Other agribusinesses and commercial farms that operate with higher capital and better technology on better lands in Odo LGA of Ogun state are also not spared from the same risks. The need to safeguard the interests and investments of local farmers and industry players in this region is therefore of paramount importance. Maintaining an increasing flow of income to rural farmers is a challenge to success of poverty alleviation programs in developing economies, due to risks and uncertainties that characterize agricultural activities. Agricultural activities are inherently risky, and smoothing consumption across years or seasons is a significant challenge for agrarian households in developing countries. Farmers and entrepreneurs in rural; agrarian economies therefore should have high demand for credit and insurance services, but the option to purchase such services as credit and insurance facilities often does not exist (Rosenzweig, 1988).

Alderman, Harold and Christina Paxson (1994) are of the opinion that most households in developing countries including Nigeria deal with economic hardships through informal insurance arrangements arising between individuals and communities on a personalized basis, rather than through markets or states. Examples include drawing down savings, engaging in reciprocal gift exchange and diversifying income-generating activities. These mechanisms can be highly effective in the right circumstances, but most recent studies show that informal insurance arrangements are often weak. In particular, poorer households in this area appear to have substantial difficulties coping even with localized, idiosyncratic risks.

In the absence of availability or access to formal insurance mechanisms in Odo LGA, Ogun state, the resource poor farmers seek to manage risks through various informal strategies. They may choose to diversify their crops, store grain, engage in informal savings and credit, favour traditional techniques over modern technology and enter into sharecropping arrangements. Informal insurance is far from perfect as vulnerable groups are faced with varied risks on a recurring basis. It provides only a partial coverage in case of systemic losses, leaving poor producers vulnerable to extreme poverty, malnutrition and also dampens long term agricultural growth. There also seems to be a tradeoff between market based risk management solutions and public or State sponsored schemes. (IFMR CIRM, 2008).

The vulnerability to income and consumption shocks makes it imperative to develop formal agricultural insurance mechanisms to cope with such risks. The traditional yield insurance schemes and the erstwhile Comprehensive Crop Insurance Scheme (CCIS) have failed to manage the risks of the poor farmers in India, as evident from their historically high payouts and poor penetration rates of State sponsored schemes, which is why this research is set up in Odogbolu LGA of Ogun state, Nigeria, to describe the socioeconomic characteristics of rural farmers and identify the problems associated with informal insurance measures in this area.

Some of the reasons for the failures of formal insurance in India are firstly, Farmers with adequate risk management capabilities were forced to purchase crop insurance in order to receive a loan. Problems were faced especially when the loan is paid up and there was lack of understanding of the benefits of agricultural insurance which leads to a fall in the demand for insurance. Secondly, the 'area approach' followed was based on the results of crop-cutting experiments where the insured farmers receives indemnity based upon the difference between the threshold yield and the yield of the crop-cutting experiments in their area. Since crop yields vary over a small area, situations exist in which farmers do not get compensated for their loss under the NAIS and farmers without insurable losses would receive payments. Thirdly, there are long delays in payment of claims to farmers due to the time-consuming crop-cutting experiments by the agriculture department which causes an erosion of income for farmers. Fourthly, physical verification of the losses proved to be very costly and often gave way to fraud as it allows for an opportunity of collusion for the assessor and the client. (IFMR CIRM, 2008) 
Problem statements. A distinctive feature of agriculture in developing countries is the level of risk, which is more apparent for those who depend on agriculture for their income. The economic, financial and production shocks which rural farmers are exposed to cause farm profits to vary hence affects the household income of rural farmers. Fluctuations in producers incomes and particularly the threat of catastrophic loss, may present difficult welfare problems for rural farmers. Therefore, the need arises for measures through which rural farmers can protect their household income.

Objective of the study. The objective of this study is to describe the socioeconomic characteristics of rural farmers and problems associated with the use of informal insurance measures in Odogbolu Local Government Area, Ogun State, Nigeria.

Significance of the study. Farmers in Odogbolu LGA of Ogun state are faced with spectrum of risks, and each of these risks along with how they manage them, impact farm income, productivity, and access to credit. Farm level surveys have indicated that the most frequently cited risks are price, crop/weather and health. These risks among others could lower farmers' anticipated income and have negative effects on their standard of living; ability to provide for themselves and their families, ability to build capital, and ability to access credit from lenders. But a well planned informal insurance will help the farmers of this area to prepare for risk and properly manage them.

\section{RESEARCH METHODOLOGY}

The study area is Odogbolu Local Government Area and is strategically located on a large expense of land of about 640sq.km and was created on the 21st September 1991 and it shares boundaries on its northern fringes with ljebu-North Local Government, in the east with ljebu-Ode Local Government, in the west with Ikenne Local Government and in the south with Epe Local Government in Lagos State. This Local Government Area has about 150 towns and villages under its jurisdiction. It has 15 wards and its headquarters is in Odogbolu.

Inhabitants of Odogbolu Local Government are Yoruba of ljebu extraction; with a population of 127,000 people according to the 2006 Census. Like any other Nigerian society, there are growing numbers of people from other ethnic groups in the country, such as the Igbos, Isokos, Urhobos, Hausa, etc. Christianity and Islam are the two main religions of the people, however there still remain sizeable number of committed traditional worshippers. The Local Government has public primary schools \& secondary schools. There are also an appreciative number of private investments in the education industry. This Local Government Area can boast of a strong traditional heritage and a sound cultural background at the head of which are enlightened royal fathers.

The people in this area are mainly agrarian, engaged in farming, hunting, fishing, lumbering and handicraft. Most of the inhabitants are involved in agriculture although a great percentage of them have other occupations. Some of the food crops grown around the area are yams, cassava maize, rice and vegetables, most of which come from the major agricultural areas in the area. Livestock production is also practiced but mainly on extensive system of production. Poultry production forms the bulk of these livestock activities followed by small ruminant production. Most of the informal insurance measures such as timeliness of operations, diversification etc are practiced as risk management techniques as well as production practices. Also, these farmers keep buffer stock to have something to fall on in case of crop failure and to ensure food security. These traditional methods of managing risks otherwise known as informal insurance measures are used by rural farmers in the study area.

Sampling procedure. The study was carried out in Odogbolu Local government area of Ogun State, Nigeria. The State was chosen because of its location in the rainforest region and the availability of food crop farmers. Also, studies on food crop farmers in the study area especially as regards issues focusing on risk in agricultural production are scarce in the literature; an attempt to fill this void provides a basis for Odogbolu as the study area. 
A two-stage sampling procedure was used in the collection of primary data in Odogbolu LGA. The first stage involved a random selection of five (5) communities from amongst the communities in Odogbolu LGA of Ogun state. The second stage involved the selection of respondents/farmers from each of the communities using the same insurance practices from the already listed informal insurance practices with probability proportionate to the size of each farming communities selected.

Data collection. Data from this study were obtained from only primary source. The primary data include the use of questionnaire and oral interview, which were duly administered to the rural farmers. These questionnaires were administered in person due to the little or no formal education of the farmers. The questionnaire schedule provided information on socio-economic characteristics of rural farmers, forms of informal insurance measures used by rural farmers. Data were also collected on the various sources of risk to agricultural products which include nature, social and economic risks. Data from 80 respondents were used for the analysis.

Data analysis. To describe the socioeconomic characteristics of rural farmers and identify various problems associated with informal insurance measures in this area, analytical tools that were used are mainly descriptive statistics such as mean, frequency, pie charts, percentages, tables and other applicable tools as indicated by responses to the respective survey questions.

\section{RESULT AND DISCUSSIONS}

Socio-economic characteristics of respondents:

Sex. In Odugbolu local government area of Ogun state, agriculture is not restricted to any particular sex, both male and female can participate actively depending on the asset each possess. But in this area, there are some factors that hinder female active participation in agriculture. These socio-economic factors range from female position in the Western culture, gender inequality to mention but few.

Out of eighty (80) farmers interviewed, 55 are male farmers representing $68.8 \%$ of the total population while 16 are female farmers representing $31.3 \%$. Below is a table showing the distribution.

Table 1 - Sex of Respondents

\begin{tabular}{|l|c|c|}
\hline Sex & Frequency & Percentage \\
\hline Female & 25 & 31.3 \\
\hline Male & 55 & 68.8 \\
\hline Total & 80 & 100.0 \\
\hline
\end{tabular}

Source: Field survey, 2010.

Majority of the farmers in the study area are males, this is as a result of the fact that the study area is an agrarian society where wealth is measured by the large size of ones land and the amount of produce one can come up with each season. In a society where women are mostly not allowed to own land and other fixed assets, men possess the much access to own these fixed assets, which therefore gives them (men) a huge advantage over their counterparts (women). For instance, In Odogbolu, at the death of the household head, his assets (including land) is majorly shared amongst the male children then little or nothing goes to the female child. As noted by Skoufias and Quisumbing (2003) that "the ability of households to enter into informal arrangement for managing risks is dependent on initial wealth". Thus, males have more assess to assets due to inheritance than females and each assets determine their ability to use informal insurance measures.

Age Distribution of the Farmers. The higher the age of the respondents the higher their experience in farming (all things being equal) and this translates to more encounter with risks among older farmers than in younger farmers. The age distribution of the rural farmers interviewed in the course of this research work is stated below: 
Table 2 - Age Distribution of the Respondents

\begin{tabular}{|c|c|c|}
\hline Age Distribution & Frequency & Percentage \\
\hline Less than 30 & 3 & 3.8 \\
\hline $30-40$ & 19 & 23.8 \\
\hline $40-50$ & 21 & 26.3 \\
\hline Above 50 & 37 & 46.1 \\
\hline Total & 80 & 100.0 \\
\hline
\end{tabular}

Source: Field survey, 2010.

From table 4.2 , majority of the respondents (46.1\%) are above 50years old and thus have more experience with informal insurance measures which they have been using for several years compared to those that are less than 30years of age $(3.8 \%)$ who are still learning from their trial and error and have less experience in the use of informal insurance measures.

Marital Status of the Respondents. A variation in income on the negative side is more felt by a married or widowed farmer than a single farmer. This is because a married or widowed farmer has more responsibilities in terms of taking care of consumption needs of family and that of himself, unlike a single person whose income is for his maintenance and consumption. The use of informal insurance measures in managing risk is of more importance to a married / widowed farmer who may not like to take chances in his production to avoid failure. As a result of this, the use of informal insurance measures increases among married and widowed farmers than among single farmers. The marital status of the respondents is stated below:

Table 3 - Marital status of the Respondents

\begin{tabular}{|c|c|c|}
\hline Marital status & Frequency & Percentage \\
\hline Single & 4 & 5.0 \\
\hline Married & 65 & 81.3 \\
\hline Widowed & 11 & 13.8 \\
\hline Total & 80 & 100.0 \\
\hline
\end{tabular}

Source: Field survey, 2010.

From the above table, it shows that the population of the respondents that were married are the highest $(81.3 \%)$ with 65 respondents being married while unmarried and widowed respondents are $4(5 \%)$ and $11(13.8 \%)$ respectively.

Household Head. Household heads take decisions including informal insurance decisions that affect the farm output and revenues as well as the standard of living of the households. Below is a table showing the distribution of respondents that head their households. Below is a table showing the distribution of respondents that head their households:

Table 4 - Distribution of Respondents who are Household Heads

\begin{tabular}{|c|c|c|}
\hline Household Head & Frequency & Percentage \\
\hline Those that do not & 25 & 31.3 \\
\hline Those that head & 55 & 68.8 \\
\hline Total & 80 & 100.0 \\
\hline
\end{tabular}

Source: Field Survey, 2010.

From the results, $68.8 \%$ of the respondents are household heads and take decisions especially on informal insurance measures while $31.3 \%$ of them are not household heads. A higher percentage of the respondents head their households which means that decisions on use of informal insurance measures is taken by them.

Educational Levels of the Respondents. A farmer's level of acquired knowledge through education determines the ability of such farmer to make profitable decisions on investment and adopt an approach to risk management that best reduces the incidences of 
production failure although experiences of farmers with risk management strategies is of more relevance. Below is a table for the educational levels attained by the respondents:

Table 5 - Educational Level of Respondents

\begin{tabular}{|c|c|c|}
\hline Educational Level & Frequency & Percent \\
\hline No formal education & 19 & 23.8 \\
\hline Primary & 27 & 33.8 \\
\hline Post-primary & 19 & 23.8 \\
\hline Tertiary & 13 & 16.3 \\
\hline Others & 2 & 2.5 \\
\hline Total & 80 & 100.0 \\
\hline
\end{tabular}

Source: Field Survey, 2010.

From the results obtained, majority of the farmers have primary $(33.8 \%)$ education while $19(23.8 \%)$ of the respondents do not have formal education. From the survey, the researcher found out from the respondents that their knowledge of informal insurance measures in managing risk is independent of the level of education they have attained rather they attributed such knowledge to be learnt from their parents, friends and neighbours.

Distribution of the Respondents Based on their Occupation. Agriculture is the mainstay of the people living in the rural areas and so farming is the major occupation in the rural areas. As a result, high income variability of farm income of rural farmers which is attributed to the risks they routinely face, some of these rural farmers engage in multiple job holdings to ensure steady flow of income into their household.

Table 6 - Occupational Distribution of Respondents

\begin{tabular}{|c|c|c|}
\hline Occupation & Frequency & Percentage \\
\hline Farming alone & 40 & 50.0 \\
\hline Farming with other jobs & 40 & 50.0 \\
\hline Total & 80 & 100.0 \\
\hline
\end{tabular}

Source: Field Survey, 2010.

The number of the respondents who depend on farming alone in the study area was forty (40) representing $50 \%$ of the total number of respondents interviewed while those with other occupations including farming was forty (40) representing $50 \%$ of the total number of farmers interviewed.

Farmers in this study area in their bid to reduce income risks engaged in other secondary activities which include office work, petty trade etc. Below is a table showing the distribution of the respondents involved in other occupations.

Table 7 - Distribution of Respondents with other Occupations

\begin{tabular}{|c|c|c|}
\hline Other Occupation & Frequency & Percentage \\
\hline Petty trading & 20 & 50.0 \\
\hline Office work & 12 & 30.0 \\
\hline Service work & 3 & 8.8 \\
\hline Crafts & 3 & 6.3 \\
\hline Others & 2 & 5.0 \\
\hline Total & 40 & 100.0 \\
\hline
\end{tabular}

Source: Field Survey, 2010.

Occupation of those farmers with other employment other than farming ranging from petty trading with the highest percentage $(50 \%)$ followed by people engaged in office work with $30 \%, 17 \%$ of the respondents are involved in service works like dry cleaning, transportation etc. while $8.8 \%$ do crafts work. Also, the researcher interviewed 3 pensioners who practice farming as well as received income as pensions. There is an increased need for diversified sources of income among farmers. The essence of diversifying income is to 
balance losses these farmers may incure as a result of crop/livestock failure and as such this non-farm income is a powerful force to compensate for lower than expected farm enterprise revenue (Reardon et al, 1998). Although an equal percentage of the respondents do not diversify their sources of income, some of them still do so as a risk management strategy.

Farming Experience. A farmer's experience in farming determines the rate of his exposure to risks and use of risk management strategy. A farmer who have spent many years in farming have more experience (due to his exposure to risks and use of informal insurance measures in managing risks) than a farmer who have spent less time in farming is presented below:

Table 8 - Distribution of Respondents According to the Number of Years Spent in Farming

\begin{tabular}{|c|c|c|}
\hline Years & Frequency & Percentage \\
\hline Below 13years & 49 & 61.25 \\
\hline Above 13years & 31 & 38.75 \\
\hline Total & 80 & 100 \\
\hline
\end{tabular}

Source: Field Survey, 2010.

The average number of years spent by all the farmers was calculated to be 13years. Therefore, above and below 13years were used to categorize the number of years spent by each respondent in farming. Forty-nine (49) of the respondents have spent below 13years in farming while thirty-one (31) respondents have spent above 13years in farming. This supports their knowledge of prevalence of risks in agriculture and the need to manage risks in agriculture and the need to manage risks and hence their dependence on tested and reliable informal insurance measures.

\section{RISK MANAGEMENT AND USE OF INFORMAL INSURANCE MEASURES BY THE RESPONDENTS}

There are various risks to which rural farmers are exposed. The perception of risks among farmers varies from one farmer to another and from place to place. Below are tables showing the distribution of respondents who have experienced losses on farm income and those that have not as well as the distribution of respondents on the ranking of risks respectively.

Table 9 - Distribution of Respondents on their experience of losses on Farm income

\begin{tabular}{|c|c|c|}
\hline Losses on Farm income & Frequency & Percent \\
\hline Never experienced losses & 20 & 25.0 \\
\hline Have Experienced losses & 60 & 75.0 \\
\hline Total & 80 & 100.0 \\
\hline
\end{tabular}

Source: Field Survey, 2010.

Table 10 - Ranking of Risks as Perceived by the Respondents

\begin{tabular}{|c|c|c|}
\hline Variables Associated with Risk & Frequency & Percentage \\
\hline Production & 46 & 32.2 \\
\hline Price & 44 & 30.8 \\
\hline Asset & 31 & 21.7 \\
\hline Personal & 18 & 12.6 \\
\hline Financial & 6 & 4.2 \\
\hline Institutional & 2 & 1.4 \\
\hline Others & 2 & 1.4 \\
\hline Total & $143^{*}$ & 100 \\
\hline
\end{tabular}

*Multiple Responses

Source: Field Survey, 2010.

Out of the eighty (80) respondents, majority of the respondents $(32.2 \%)$ perceived production / yield risks as the risk they were highly exposed to. Such yield / productivity risks 
were often related to weather (excessive or insufficient rainfall, extreme temperatures) and plants and animal diseases. This was in line with their production programme as most of the respondents were involved in different crop production. After production/yield risks, price risks was the second ranked by the respondents. This was attributed to high costs of input (like yam) as most of them grew yam and low costs of output especially when most of the farmers harvest at the same time, prices of output fall. Institutional risk was least perceived among the respondents not because government policies were mainly targeted at rural farmers but because most of their activities were usually carried out on small scale which made them not to properly benefits from various governmental policies and incentives for farmers. The perception of risks among farmers varies from place to place. For instance, in a survey on risk perception in the Dutch livestock sector carried out in 1997, price risk was identified as the major source of risk, followed by personal and institutional risk. Financial risks were perceived as the least important (Meuwissen, Huirne and Hardaker, 1999a). For the U.S., similar survey in 1996 showed that risk perception differed depending on the production programme. Wheat, corn, and soybeans producers, for example, were most concerned about production/yield risks and price risks. Whereas livestock farmers perceived institutional risks as particularly high (USDA, 1999). An analysis of the above statements shows that a risk perception varies from place to place and depends on production programme of farmers. From the results obtained, price risk and production /yield risk among others coincide with the U.S. case as the highly perceived risks among farmers. The respondents perceived price risk most likewise in the Dutch Survey cited above.

\section{PROBLEMS ENCOUNTERED BY THE RESPONDENTS}

All the measures used had factors that limited their effectiveness. Majority of the farmers (61\%) identified their major problems with the use of informal insurance measures as entry constraints. While others $(19 \%)$ claimed not to have any problem using the informal insurance measures. All the respondents said they encountered entry constraints. These entry constraints were caused by factors such as lack of working capital, lack of access to credit and lack of skills. Below is the table showing the distribution of the respondents on the problems encountered in the use of informal insurance measures and the distribution of the respondents on the factors that cause entry problems for them:

Table 19 - Distribution of Problems that Lead to entry Constraints among the Respondents

\begin{tabular}{|c|c|c|}
\hline Problems & Frequency & Percent \\
\hline Lack of credit & 50 & 39.7 \\
\hline Lack of Credit facilities & 15 & 11.9 \\
\hline Lack of working capital (assets like land) & 44 & 34.9 \\
\hline Lack of skills (education) & 17 & 13.5 \\
\hline Total & $126^{*}$ & 100.0 \\
\hline
\end{tabular}

*Multiple Responses

Source: Field Survey, 2010.

Majority (50) identified lack of credit as their major obstacle that stops them from using informal insurance measures. This left them with activities with low entry costs. Only 17 of the respondents identified lack of skills as their problem. Their reason was that nonagricultural wage was restricted to people with education. Forty-four (44) of the respondents identified lack of working capital as their problem which reduces their ability to enter into a diversification programme with a higher return. Their problem of capital was as a result of low-asset base which makes it difficult for them to borrow or even sell assets as a buffer stock strategy. All these problems lead to entry barriers for the respondents which CSAE (2000) identified entry barriers as the major constraints to the use of informal insurance measures among farmers. 


\section{SUMMARY}

Agriculture is very much vulnerable to the unpredictability of nature. With agricultural production representing the major livelihood of many resource constrained Odogbolu farmers, the impact of agricultural risks cannot be taken lightly. Other agribusinesses and commercial farms that operate with higher capital and better technology on better lands are also not spared from the same risks. The need to safeguard the interests and investments of local farmers and industry players is therefore of paramount importance. Farming is a highrisk business. It is established fact that farmers should use the best seeds, chemicals and management practices, but the weather can still destroy crops. Since one cannot control disasters, it becomes wise to transfer some of the risks by way of insurance in exchange for a manageable premium that can be a part of farmer operating budget.

Household in developing countries continue to face considerable risk, threatening their livelihood. This work discussed the major risk sources which include market failure, price fluctuation, production/yield failure, are highly perceived among the respondents while institutional and financial risks are less perceived. On the problems encountered by the respondents, they identified factors like lack of access to credit and credit facilities, lack of working capital, lack of skills, high costs of inputs as problems, active as entry barriers to their use of informal insurance measures leaving them with low-return and low risk activities.

\section{CONCLUSIONS}

In the absence of availability or little access to formal risk management mechanisms in Odogbolu area of Ogun state, the asset rural households seek to manage risks through various informal strategies. They may choose to diversify their crops, store grain, engage in informal savings and credit, favour traditional techniques over modern technology and enter into share-cropping arrangements. Since the rural farmers are now aware of the use of informal insurance measures, the rural farmers are likely to engage in low risk, low return activity portfolios. This is not because the rural farmers have different inmate preferences - a psychological trait that makes them less entrepreneurial. Diversifying income sources is useful but because rural farmers are poor, it may come at a high cost, in terms of levels of income and procurement of inputs. Nevertheless, observing specialization does not necessarily imply that the household follows a high risk strategy. Poverty allocation strategy should not focus only on reducing the head count poverty rate or the percentage of rural households to total population. Policy objective should be to reduce the level of vulnerability to poverty by providing mechanisms for the rural farmers to manage risk.

\section{RECOMMENDATIONS}

The effectiveness of risk management of rural farm households is an empirical issue. The essence of carrying out a survey on the use of informal insurance measures among rural farmers in managing risks is to show the effectiveness of using these measures as well as identify the problems they may encounter. Promoting diversification is not necessarily a solution but finding ways of reducing constraints into profitable low-risk activities.

Based on these findings, I recommend the following factors to be adopted to improve the effectiveness of using informal insurance measures by rural farmers.

In the course of this research, it was discovered that majority of the farmers were poorly educated and they barely have a post-primary education, therefore, the government should initiate a more fierce Agricultural extension programme to train and improve the knowledge, attitude and technical skills of the rural farmers.

The government should give concessions to the rural farmers in various aspects which include provision of credit facilities, provision of infrastructures and inputs for rural farmers to enable them perform most of the informal insurance measures. 


\section{REFERENCES}

1. Akintola JO (1999), Forecasting food crop yields from meteorological variables. J.of Econs. and Social Development Vol. 14, No.1, 24-33.

2. Alderman, Harold (1996), "Saving and Economic Shocks In Rural Pakistan," Journal of Development Economics 51(2) 343-366.

3. Alderman, Harold and Christina Paxson (1994), "Do the Poor Insure? A Synthesis of the Literature on Risk Sharing Institutions in Developing Countries," in Economics in a Changing World: Proceedings of the Tenth World Congress of the International Economics Association, Moscow, London: MacMillan Press.

4. Anand, Sudhir and Jonathan Morduch (1999), "Poverty and the 'Population Problem'," in Gustavo de Santis and Massimo Livi-Bacci, eds., Population and Poverty in the Developing World. Oxford: Oxford University Press/IUSSP.

5. Banerjee, Abhijit and Andrew Newman (1998), "Information, the Dual Economy, and Development," Review of Economic Studies 65 (4), October: $631-654$.

6. Baquet $A$, Hambleton $R$ and $D$ Jose Introduction to risk management. In: Wesley, N.M., George, F.P. and Ullerich, S. (2002). Demonstrating differences in risk attitudes, J. of American Society of Farm Managers and Rural Appraisers ASFMRA

7. Besley, Timothy (1995a), "Non-Market Institutions for Credit and Risk-Sharing in LowIncome Countries," Journal of Economic Perspectives 9 (3), 115 - 127.

8. Besley, Timothy (1995b), "Savings, Credit, and Insurance," in Jere Behrman and T.N. Srinivasan, eds., Handbook of Development Economics, vol. 3. Amsterdam: NorthHolland.

9. Coate, Stephen and Martin Ravallion (1993), "Reciprocity without Commitment: Characterization and Performance of Informal Insurance Arrangements," Journal of Development Economics 40 (1), February, $1-24$.

10. Cochrane, John (1991), "A Simple Test of Consumption Insurance," Journal of Political Economy 99 (5), $957-976.33$

11. Corbett J (1988), Famine and household coping strategies. In: World Development, vol. 16, No. 9,1099-1112

12. Cox, Donald and Emmanuel Jimenez (1997), "Coping with Apartheid: Inter-Household Transfers over the Life-Cycle in South Africa," Boston College and World Bank, draft.

13. Cox, Donald and Emmanuel Jimenez (1998), "Risk-Sharing and Private Transfers: What about Urban Households?" Economic Development and Cultural Change 46 (3), April, $621-639$.

14. Czukas, Katherine, Marcel Fafchamps, Christopher Udry (1998), "Drought and Saving in West Africa: Are Livestock a Buffer Stock?" Journal of Development Economics 55(2), 273-305.

15. Das Gupta, Monica (1987), "Informal Security Mechanisms and Population Retention in Rural India," Economic Development and Cultural Change 13 (1), March, $101-120$.

16. Deaton, Angus (1997), The Analysis of Household Surveys. Baltimore: World Bank/Johns Hopkins University Press.

17. Dismukes R (2005), Farm Risk Management http//www.ers.usda.gov/Briefing/risk Management.

18. Fafchamps, Marcel (1992), "Solidarity Networks in Preindustrial Societies: Rational Peasants with a Moral Economy," Economic Development and Cultural Change 41 (1), October, $147-173$.

19. Foster, Andrew and Mark Rosenzweig (1999), "Imperfect Commitment, Altruism and the Family: Evidence from Transfer Behavior in Low-Income Areas," Department of Economics, University of Pennsylvania, draft.

20. Gertler, Paul and Jonathan Gruber (1997), "Insuring Consumption Against Illness." Cambridge, MA: NBER Working Paper 6035.

21. Hardaker, J. b,, Huirne, R. B. M and Anderson, J. R. (1997). Coping with Risk in Agriculture. Washington: CAB International. pp.32-34. 
22. Harwood J, Heifner R, Coble K, Perry T and A Somwaru (1999), Managing risk in farming: concepts, research and analysis. Agric. Econs. Report No. 774. Market and Trade Economic Division and Resource Economics Division, Economic Research Service U.S.Department of Agriculture.

23. Hoff, Karla (1997), "Informal Insurance and the Poverty Trap," Dept. of Economics, University of Maryland, draft, January.

24. Institute for Financial Management and Research (IFMR CIRM) - Centre for Insurance and Risk Management (2008). An International Agricultural Journal.

25. Isik M (2002) Resource Management under Production and Output Price Uncertainty. Implication for Environmental Policy. American J. of Agric. Econs. 84 (3), 557-591.

26. Jacoby, Hanan and Emmanuel Skoufias (1997), "Risk, Financial Markets, and Human Capital in a Developing Country," Review of Economic Studies 64 (3), July, 311 -336.

27. Jalan, Jyotsna and Martin Ravallion (1997), "Are the Poor Less Well Insured? Evidence on Vulnerability to Income Risk in Rural China," World Bank working paper, draft.

28. Jensen, Robert (1998), "Public Transfers, Private Transfers, and the 'Crowding Out' Hypothesis: Theory and Evidence from South Africa," John F. Kennedy School of Government Faculty Working Paper Series, R98-08, June.

29. Jonathan Morduch (1999) Between the Market and State: Can Informal Insurance Patch the Safety Net? Summer Research Workshop on Poverty, Washington DC.

30. Khandker, Shahidur (1998), Fighting Poverty with Microcredit: Experience in Bangladesh. New York: Oxford University Press and The World Bank.

31. Kletzer, Kenneth and Brian Wright (1998), "Sovereign Debt as Intertemporal Barter," University of California, Berkeley, Center for International and Development Economics Research Working Paper C98-100.

32. Kochar, Anjini (1999), "Smoothing Consumption by Smoothing Income: Hours-of-Work Responses to Idiosyncratic Agricultural Shocks in Rural India," Review of Economics and Statistics 81 (1), February, 50 - 61.

33. La Ferrara, Eliana (1997), "Ethnicity and Reciprocity: An Analysis of Credit Transactions in Ghana," Dept. of Economics, Harvard University, draft.

34. Ligon, Ethan, Jonathan Thomas, and Tim Worall (1997), "Informal Insurance Arrangements in Village Economies," Dept. of Agricultural and Resources Economics, draft, January.

35. Lim, Youngjae and Robert Townsend (1998), "General Equilibrium Models of Financial Systems: Theory and Measurement in Village Economies," Review of Economic Dynamics 1 (1), January, 59 - 118.

36. Lipton, Michael and Martin Ravallion (1993), "Poverty and Policy," in Jere Behrman and T.N. Srinivasan, eds., Handbook of Development Economics, vol. 3. Amsterdam: NorthHolland.

37. Lund, Susan and Marcel Fafchamps (1997), "Risk-Sharing Networks in Rural Philippines," Department of Economics, Stanford University, draft.

38. Meuwisssen, M. P. M., Huirne, B. M and Hardaker, J. B. (1999). Income Insurance for Individual Farmers: Feasibility for European Agriculture Organized Session Papers. IXEuropean Congress for Agricultural Economists, pp.428-444.

39. Morduch, Jonathan, (1994), "Poverty and Vulnerability," American Economic Review 84, May: $221-225$.

40. Okunmadewa F (2003) Risk, vulnerability in agriculture: concept and context. A paper presented at staff seminar, Department of Agricultural Economics. , University of Ibadan.

41. Paulson, Anna (1995), "Insurance Motives for Migration: Evidence from Thailand," Princeton University, draft.

42. Platteau, Jean-Philippe (1991), "Traditional Systems of Social Security and Hunger Insurance," in E. Ahmad, J. Drèze, J. Hills, and A. Sen, eds., Social Security in Developing Countries. Oxford: Clarendon Press.

43. Platteau, Jean-Philippe (1987), "Traditional Sharing Norms as an Obstacle to Economic Growth in Tribal Society," chapter 5 of J.-P. Platteau, Institutions, Social Norms, and Economic Development, Harwood Publishers. 
44. Ravallion, Martin (1991), "Reaching the Rural Poor Through Public Employment: Arguments, Evidence, and Lessons from South Asia," World Bank Research Observer 6 (2), $153-175$.

45. Ravallion, Martin and Shubham Chaudhuri (1996), "Risk and Insurance in Village India: Comment," Econometrica.

46. Ray PK (1980) Agricultural insurance: principles, organization and application to developing countries. 2nd Edition, Pergamon Press, Oxford England.

47. Reardon, Thomas (1997), "Using Evidence of Household Income Diversification to Inform Study of the Rural Nonfarm Labor Market in Africa," World Development 25 (5), 735 747.

48. Reardon, Thomas, Peter Matlon, and Christopher Delgado (1988), "Coping with Household-Level Food Insecurity in Drought-Affected Areas of Burkina Faso," World Development 16 (9), 1065 - 1074.

49. Rose, Elaina (1995), "Consumption Smoothing and Excess Female Mortality in Rural India," Review of Economics and Statistics 81 (1), February, 41 - 49.

50. Rosenzweig, Mark (1988), "Risk, Implicit Contracts, and the Family in Rural Areas of Low-Income Countries," Economic Journal 98 (393), 1148 - 1170.

51. Rutherford, Stuart (1999), "The Poor and Their Money," Finance and Development Research Programme Working Paper Series 3/99. Manchester, UK: University of Manchester Institute for Development Policy and Management.

52. Skoufias, E. and Quisumbing, A. R. (2003). Consumption, Insurance and Vulnerability to Poverty: A Synthesis of the Evidence from Bangladesh, Ethiopia, Mali, Mexico and Russia.

53. Subbarao, K., Aniruddha Bonnerjee, Jeanine Braithwaite, Soniya Carvalho, Kene Ezemenari, Carol Graham, and Alan Thompson (1997), Safety Net Programs and Poverty Reduction: Lessons from Cross-Country Experience. Washington, DC: The World Bank.

54. USDA, Economic Research Service (1999). Managing Risk in Farming: Concepts, Research and Analysis. Washington DC.

55. Walker, Thomas, R. P. Singh, and M. Asokan (1986), "Risk Benefits, Crop Insurance, and Dryland Agriculture," Economic and Political Weekly 21, June, A81 - A88.

56. World Bank (1994), Zambia Poverty Assessment, vol. 5 (Participatory Poverty Assessment), Washington, D.C.

57. World Bank (2001) Dynamic Risk Management and the poor: Developing a Social Protection Strategy for Africa", Africa Region Human Development Series. Washington DC, USA.

58. World Bank Swaziland (2000): Reduction poverty through shared growth". Poverty policy study overview Report. Human Development Group1, Africa Region. Washington, D.C.

59. Yaron, Jacob, McDonald Benjamin, and Gerda Piprek (1997), Rural Finance: Issues, Design, and Best Practices. Washington, D.C., World Bank, draft.

60. Zeller, Manfred, Gertrud Shrieder, Joachim von Braun, and Franz Heidhues (1997), Rural Finance for Food Security for the Poor. Food Policy Review 4, Washington, D.C.: IFPRI. 